\title{
EVALUATING 'REGISTERIAL' NORMS IN ADVERTISING TEXTS: A SYSTEMIC PERSPECTIVE
}

\author{
Taofeek Olaiwola Dalamu \\ University of Lagos \\ Nigeria
}

\begin{abstract}
Language and social concerns facilitate every communicative text. Based on that, the study considered the advertising text, as a test ground to explore the relationships between language and socio-cultural norms as revealers of the Register of advertising. Considered for the investigation are ten advertisements of Guinness ${ }^{\circledR}$, Peak Milk ${ }^{\circledR}$, Gulder $^{\circledR}$, Coca cola $^{\circledR}$, Pepsi $^{\circledR}$, Stanbic IBTC ${ }^{\circledR}$, etc. upon which Ideational, Interpersonal and Textual Metafunctions served as tools of analysis. Besides the report that Material Processes such as come to, reshaped, make, and is wasting dominate the contents, a Behavioral Process of rests on also performs a role in the Register analysis. The study further reveals digitization (*945\#), local language intrusion $(O g a)$, personification (bourn = born), clipping (diff) as context devices in the business environment. There are also Register(s) of neologism (Pecadomo), poetic and sermonized texts to persuade recipients. As the investigation has revealed SFL as a viable processor of Register(s), it thus suggests that its application to other texts outside advertising might yield meaningful results. Such exercise could assist in the understanding of novel items that could contribute to language constructs and development.
\end{abstract}

Keywords: Context of situation, ideational metafunction, interpersonal metafunction, register, textual metafunction

\section{INTRODUCTION}

The composition of every communicative text follows a socio-cultural design. Halliday and Hasan (1985) recognize that to prioritize a text as a product of a process that plays uncompromising roles in a social structure. Besides that, the patterning of a text parallel to social norms is as a result of the background of the encoder and decoder as well as the relationships that language creates between the communicators. The social consideration enables a text, in which advertising is part, to be more meaningful (Sinclair, 1981) most especially in the realms of lexemic organization and utilization. And particularly, advertising practitioners are aware of social concerns 
(Dalamu, 2018a). That is the motive for constructing their texts in a direction that can fascinate readers. Meaning that, the advertising industry intentionally communicates in a certain way that appears to differentiate the stimulating devices from other forms of writing techniques. By that, one could characterize advertising as a genre of its class.

In that regard, the matter of registerial norms becomes an issue that informs the writer to accommodate advertising within the domain of Register. Thus, the advertising language contains specific facilities as a means of achieving social goals of persuasion. As experts make certain choice lexicons to excite the audience, the distinctiveness of the elements separates advertising from other styles of writing systems. The terminology of style influences the study to evaluation of the contents there in. By evaluation, the investigation subscribes to a particular behavior of the appraisal of the communicative texts of advertising. In other words, evaluation suggests the author's analysis of the nitty-gritty of texts regarding the composition of the connective tools of communication in terms of language and its immediate environment. However, going by the perception of Halliday (1985), the personal judgment is metaphorically inclined on the basis that the personal view is incorporated within non-personal resources. This refers that the examination is the author's but the materials involved are sorted outside the confinement of the author.

Appreciating advertising from the view that its activities are as old as human beings, one could then expect that literature on advertising texts is enormous (Dalamu, 2017e). Advertising texts have connections with psychology, sociology, philosophy, linguistics, etc. In addition, the social nature of advertising positions it to have unbroken links with all subjects of social concerns. A notable personal valuation (Winter, 1982; Hoey, 1983) of Leech (1966) discusses advertising from a linguistic perspective expounding the phenomenon from a purely structural content. Of historical significant is Williamson (1978) where semiotic analysis dominates the scene. Other interest areas are on pragmatic (Tanaka, 1988), metaphorical (Foreceville, 1996), pidginization (Dalamu, 2017c) and communicative (Dyer, 2005) characteristics of advertising. The communicative components of advertising are concerns of Geis (1982), Myers (1994), Hermeren (1999) and Cook (2001). As McCarthy and Carter (1994) exemplify contrastive thematic exponents so is Fairclough (2001) discusses the matter of power domineering roles in advertising. Moreover, Wicke (1988) examines fictitious etiquettes while Geiszinger (2001) constructs the historical language of advertising from a quantitative perspective. This paper adopts a quantitative and qualitative point of view, as an extension of earlier efforts, to investigate the style of advertising texts. On the one hand, the approach is an exposition of the linguistic features as employed to sensitize recipients. On the other hand, the investigation analyzes the texts with the application of technological tools of tables and graphs to evaluate the frequency of the communicative exponents 
of advertising texts, utilized as a winning strategy among the Nigerian readers.

\subsection{Literature review}

The descriptions of Register from different scholarly perspectives in terms of definitions and regions of operations dominate the literature review. The roles of the Halliday's three metafunctions on the analysis of Register have also been discussed.

\subsubsection{Register, a Problematic Discernment}

The terminology of Register seems nebulous. This is because Register has generated argumentative charges from scholars. The struggle is not really because of how to realize the concept but because of its interconnectivity with Style, Dialect, Genre and other notional domains in relation to explanations. The interdisciplinary link of Register, as well, serves as another factor for creating specific controversial opinions for it. Owing to the above remarks, Register has received a critical appraisal from Crystal and Davy (1969) thus;

The criticism of inconsistency can best be illustrated from the use of the term register (which is a fundamental notion in 'Neo- Firthian' stylistics). This term has been applied to varieties of language in an almost indiscriminate manner, as if it could be usefully applied to situationally distinctive pieces of language of any kind. The language of news-paper headlines, church services, sports commentaries, pop songs, advertising and football, amongst others, have all been referred to as registers in one work [M. A. K.] Halliday, A. MacIntosh, P. D. Strevens, The Linguistic Sciences and Language Teaching] . . .[T]here are very great differences in nature of the situational variables involved in these uses of English, and . . . it is inconsistent, unrealistic, and confusing to obscure these differences by grouping everything under the same heading (p. 61).

Register in the perspective of Crystal and Davy (1969), has been 'haphazardly' deployed as an over-generalized device of the function and form of language. That is, Register is a term used to cover a broad horizon of the style of language deployment. The continuum of its accommodation has perhaps persuaded its uses without creating a boundary for it. However, the academic dictate of shades of opinions could have influenced the differentiation between Register and Dialect (Halliday, MacIntosh \& Strevens, 1964, p. 77), Register and Style (Brook, 1973, p. 13), and Register 
and Genre (Frow, 1980, p. 78; Martin, 1985, p. 250; Martin \& Rothery, 1986, p. 243; Conture, 1986, p. 82-87). And particularly, Leckie- Tarry (1993, p. 2833) provides a systematic view on the differences between Register and Genre conceptual frameworks. In the furtherance, Zwicky and Zwicky (1982) classify that there are Linguistic conceptual spheres that qualify as Register (child language, newspaper headlines, restaurant menus, etc.) and those outside the scope of Register (football commentary, advertisement, etc.). Irrespective of the shade of views, one thing that is clear is that Register has a specialized domain as well as creating an existing overlap with other conceptual field of Genre, Dialect, Ideology, language teaching, lexicogrammar, sciences, and social roles (Ghadessy, 1993) in varying degrees. As it is associated with Stylistics and texture (Butler 1985, p. 67) so also it is to intonacity and onset level of brain (Cruttenden, 1986, p. 129; Couper-Kuhlar, 2002, p. 21). In that respect, De Beaugrande (1993) attempt to douse the arguments commending that when one selects a register to investigate, one must do so to elicit some response (p. 17-18). Then Register, by De Beaugrande theorization, is imprecise for it accommodates elements of uncertainly. It is protean as well as amoebic. To this end, Register is an embodiment of contextualized mental acceptability and moral conviction as it is acquired in specific communications among interlocutors.

The study's point of departure is to say that Register has accumulated historical background, though the term escapes the approaches of Saussurean abstract systems, Sapirean linguistic determinism and Bloomfieldian minimal units (ibid., 1993). It is reported that Reid (1956) coins the lexeme, Register, and cultivated extensively by Ure (1968). Meanwhile, ASL (nd) articulates that Joos (1967) contributes to the knowledge and theoretical applications of Register most especially in the realm of American Sign Language as a linguistic spectrum in the social domain. On this historical plane, Halliday $(1967 / 8)$ as earlier mentioned contextualizes the discourse by exploring the wh-questions of who, why, where, what, how and when communicative facilities to generate meaning potential. Of a note are the contributions of Ellis and Ure (1968) to the active development of Register in a systemic framework to the teaching of English to foreign language learners (Halliday, 1985, p. 4). Since these historical regimes the expounding of linguistic features of texts has begun to receive variegated descriptions of significance.

There are little doubts that a variety of language in parallel with its use will attract many definitions. Among others, ASL (nd) posits that Register is the employment of text (lexicon, syntax, intonation, semantic intent) and specific content in order to create a social and psychological distance between the encoder and decoder. The social action in a way reflects the height of the social distance that the user desires to have with the audience in a specific situation (also in Giles, Scherer \& Taylor, 1979, p. 343). One could then subscribe this view to some tendencies of Register in relation to intonicity, sociolinguistics, systemic linguistics and stylistics (Butler, 1985; Hymes, 
1974a \& 1974b, Brook, 1973, Ferguson \& Snow, 1977, Webster, 1993; Cross, 1993, Ferguson, 1994). Regarding intonicity, Kouper-Kuhlen (2002, p. 21) says that Register is the relative position in the speech phrase within an interlocutor's overall voice maximum distance of capability. The scope indicates the configuration of the pitch range.

From a sociolinguistic dimension, Ferguson (1977, p. 212) claims that Register operates in a given language and given speech community with appropriate and a set of structural features. These norms differentiate a community from the total repertoires of others. Ferguson's thought is more of socio-cultural for it distinguishes and connects linguistic features of a text with cultural proprieties of a people. When one observes language use in various situations, following Halliday, MacIntosh and Strevens (1964) very closely, there are differences in the kind of 'language selected as appropriate to different types of situation' (p. 87). It is in that sense that Gregory and Carroll (1978) describe Register as 'an instance of language-in-action' with peculiar indexical markers of the linguistic forms. The visible structures placed the texts as containing common-core features are the embodiment of registerial norms (p. 64-67). To Gregory and Carroll, Register is an expose of distinctions of language to varying degrees of social settings. The manifestation of Register in stylistics, in Halliday's (1978) sense, is articulated thus:

A feature that is brought into prominence will be 'foregrounded' only if it relates to the meaning of the text as a whole. This relationship is a functional one: if a particular feature of the language contributes, by its prominence, to the total meaning of the work it does so by virtue of and through the medium of its own value in the language - through the linguistic function from which its meaning is derived. Where the function is relevant to our interpretation of the work, the prominence will appear as motivated. (p. 112).

That remark submission refers that every text with semantic resources are constructed with a particular pattern of style.

Although phonological, sociolinguistics and stylistics appreciation of Register are significant, the study's approach is the Systemic Functional Linguistics (henceforth: SFL) model because of its strong emphasis on Register. The exposition began from Halliday, MacIntosh and Strevens (1964) to the present day, which considers a variety of language deployment according to use. To a considerable extent, SFL has attempted to lay bare the challenges of Register by removing a veil of its fuzziness, which Gieszinger (2001, p.14) exclaims problematic. Beginning from Halliday himself, Register is considered as "the configuration of semantic resources that the member of a culture typically associates with a situation type. It is the meaning potential that is accessible in a given social context' $(1978$, p. 111). Three things 
characterize the Halliday's point of view. These are: meaning potential, cultural norms, and specific settings. The categorization runs along with the form of texts. One could argue then that linguistic features are in partnership with social concerns, phonological and grammatical terms, psychological and philosophical issues (Giles, Scherer \& Taylor, 1979). The abstractions are associated in a way with social variables of sex, age, social class, etc. as a means of analysis to realize meaning potential.

Sometimes, social concerns are accompanied with non linguistic facilities that contribute to the meaning-making of texts (Zwicky \& Zwicky, 1980). Consequently, Hymes (1974) observes that Register is associated with specific textual atmosphere in which one can derive the functions of language. In that regard, Register assists analysts to differentiate genre typologies. That might be the motive for Martin (1993) to pinpoint Register as the derivative of semantic resources of the geography of genre. According to Martin, that is the plane where the descriptions of the linguistic features (or configurations) of texts are mapped out. Following Firth (1968), Halliday (1978) and Martin (1993), Lemke (1985) recapitulates Register from five possibilities of paradigmatic system, restricted meaning potential, typology of contextual situation, language systems for particular purposes and expression of connotation relations (p. 276-279). Therefore, Halliday (1978) adds that a linguist needs to ask 'which kinds of situational factor determine which of selection in the linguistic system?' (p. 32) in order to understand the concept of Register in its axes.

\subsubsection{Theoretical framework: Three metafunctional triad}

From the foregoing, Register represents a communicative event for a particular contextual setting. This seems to have persuaded Johnstone (2008) to expound the terminology as 'a set of lexical (vocabulary) and grammatical features that accompany and help to identify discourse that occurs in a particular recurrent situation (also in Ferguson, 1985; Fairclough, 1992). The reflections of lexis, grammar, discourse and context, in Johnstone's perspective, are the contents of Register. These variables position the Halliday's (1994) three Metafunctions highly relevant to the analysis of Register in relation to advertisements, serving as data of the investigation. There are two arms of the Metafunctions. That is, the grammatical aspect and the contextual inclination. Ideational, Interpersonal and Textual Metafunctions have their grammatical transposes as Transitivity, Mood and Theme whereas their contextual symbols operate as Field, Tenor and Mode (Dalamu, 2017b).

One could suggest that Ideational Metafunction is divided into experiential and logical relations. In that respect, Halliday (1994, p. 20) claims that the Ideational Metafunction exhibits the content of the goings-on in a text. When a communicator uses language to interact, Halliday and 
Matthiessen (2014) emphasize that the individual uses it to express either the world around him/her or the world within him/her. Eggins (2004) observes further that one uses words to talk about his/her experience - to construct the world - where 'some entity does something' (p. 213-215). Ravelli (2000) remarks that the world around a speaker, the external world could be things, events qualities, etc. A communicator's internal world could also be represented as - thoughts, beliefs, feelings, etc. Halliday (1994) further describes 'experience' as consisting of goings-on - happening, doing, sensing, meaning, and being and become. He adds that 'the clause is also a mode of reflection... and flow of events' (p. 106). A language user, Halliday asserts, articulates his/her thoughts to explicate meaning potential in confidence. These utterances are regarded as texts that are contextually-produced with a particular content. Kress and van Leeuwen (2003, p. 47) explain that the contents are determined by the speaker with specific meanings embedded thereof. As a result of that, language seems to possess numerous resources that are employed to represent the entities in the world. In support of that, the module of realizing and analyzing meanings from this perspective, Thompson (2004, p. 88-89) claims, is called transitivity system. Also, Thompson (2014) suggests that the Process is brought about, most times, by nominal elements (Participants) involved in the event of negotiating and exchanging interactions. It is also possible that a text may have circumstantial elements. Such elements function in the appropriate parts of the clause which sometimes relate the content with further information.

The interpersonal Metafunction occupies two domains of grammatical exemplification. The first is mood that refers to the grammatical structures of declarative, imperative, interrogative and modulated interrogative positions of the clause (Eggins, 2004). The second aspect indicates the organs of the clause, which function as Subject and Finite. However, the remaining structures are in the orbit of Residue. Predicator, Complement and Adjunct dominate that space (Fontaine, 2013). Following Halliday and Matthiessen (2004) on the grammatical structures, an interactant does two things. The individual is either giving information or demanding something from the listener. By implication, Bloor and Bloor (2013) deduce four positions of the language utilized. That is, giving goods and services, demanding goods and services, giving information, and demanding information. Halliday and Matthiessen (2014) construct these communicative stances as offer, command, statement and question. That influences Thompson (2014) to remark that the four functional roles illustrate the interactant's contributions to the social 'interact' of goings-on.

Perhaps, the Theme expresses the element which serves as the point of departure of the message. It is that which 'locates and orients the clause within its context remainder of the message' (Halliday \& Matthiessen, 2004, p. 64-65). From the description of Halliday and Matthiessen, the Theme depicts how a speaker organizes the communicative repertoire, and connects 
the mandated textual structures with meaning. Rashidi (1992) reveals that the concepts, Theme and Rheme, originated from the Prague school. The scope of the textual structure also covers cohesion and informational structure (Halliday \& Hasan, 1976, p. 1-5, Bloor \& Bloor 2004, p. 64-81). The study is limited to Theme and Rheme for conciseness. The Theme comes first and the Rheme second in the clause structure (De Beaugrande, 1991, p. 345). However, Rashidi (1992) further explains that the Rheme is not the foundation but the 'heart' of the message of the encoder. Scholars, in Ravelli's (2000, p. 57) perspective, need to consider thematic development, the way in which the Theme patterns unfold in the text. This is because the Theme operates in various forms and functions of Unmarked Theme, Marked Theme, Topical Theme and Thematic Theme (Martin \& Rose, 2013; Dalamu, 2017d).

The context of situation (henceforth: COS) has its source in anthropology. On the ground that it is Malinowski (1923) that proposes the influences of social norms in language, based on his exploration of the Kiriwinian language in the Trobrian Islands. Firth (1950) receives the fire to explain text in terms of its environment. The approach of Firth to COS covers participants, verbal and non-verbal communicative actions, other relevant features, and the effects of the text (Butler, 2003a \& 2003b). Of importance are the contributions of Mitchell and Hymes, serving as the renewal of social influences on language. Channel, participants, key, content, and genre etc. are considerable factors of social norms in linguistics (Halliday \& Hasan, 1985; De Beaugrande, 1993). Following the perspectives of Malinowski, Firth, etc., Halliday (1978) argues that a text is a social semantics, enhancing the exchange of meanings. It is a process and a product with the parameters of Field, Tenor and Mode - of discourse. Although, Martin (1992) claims that the contextual coinages oscillate between (Halliday, MacIntosh \& Strevens, 1964) and (Gregory, 1967; Ure \& Ellis, 1977; Uribe-Villegas, 1977), the influence of Halliday (1978) is fundamental most especially in relation to the three Metafunctions as well as Register (also in Halliday, 1980a, 1980b \& 1980c). In respect to that, Thibault (1987, p. 610) comments thus;

I would see the notion of register as being at the semantic level, not above it. Shifting is register mean re-ordering the possibilities at the semantic level, whereas the categories of field, mode and tenor belong one level up. These are the features of the context of situation; and this is an interface. ...the register itself ... is a setting of possibilities in the semantics.

The analysis of Register provides meanings to texts. As Register operates within the semantic level, in the point of view of Thibault, the trajectory of Field Tenor and Mode are possible tools of meaning derivatives. In sum, Eggins and Slade (1997, p. 51) suggest that 'The tripartite structure of 
language is... an encoding of the tripartite of the contexts of situation... we use. So, the systemic pursuits in the analysis of data through Register are the logical extension of Halliday's insights. Figure 1 below demonstrates the interface as well as the relationships between grammatical and contextual aspects of the Halliday's model of Register analysis.

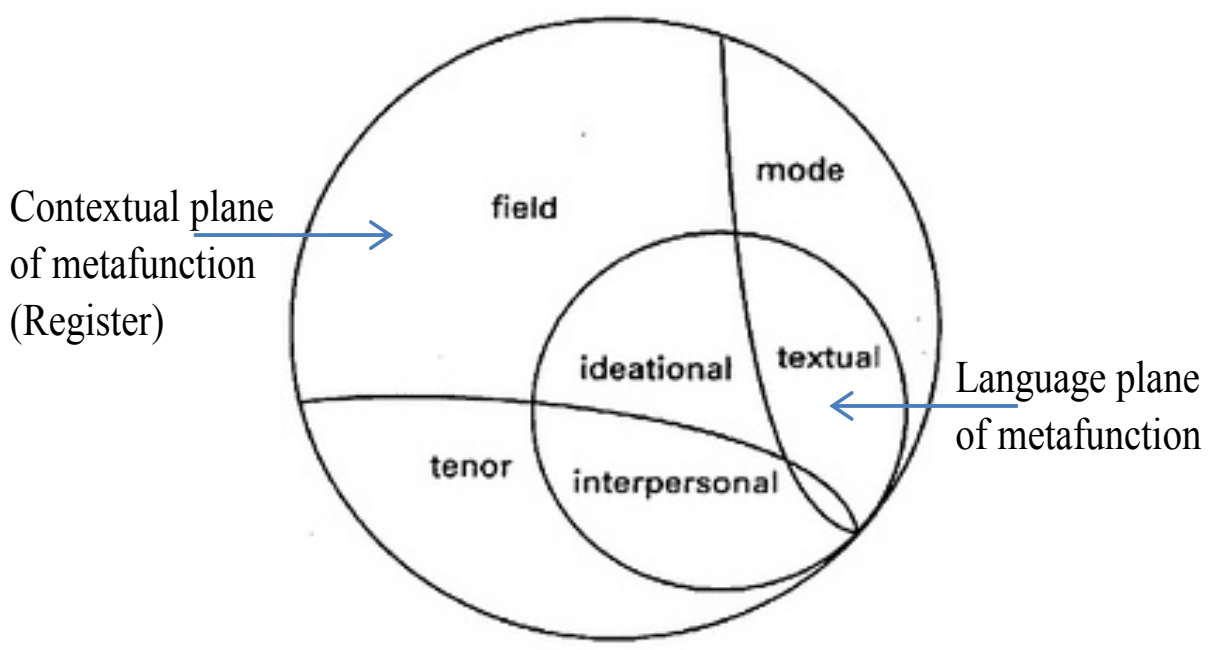

Figure 1: Domains of Three Metafunctions in Register (Eggins \& Martin, 1997)

Figure 1 above exemplifies the three Metafunctions in terms of structural arrangement and contextual organization in the domain of text. Ideational (Field) is the systems of activity in focus; Interpersonal (Tenor) represents the social relationship of participants; and Textual (Mode) demonstrates the channel of communication as in the extent and possibilities of feedback (Martin, 2002; Kołata, 2010).

\subsection{Research questions}

What are the registerial devices of advertising texts? And how do elements of the immediate setting of advertising industry influence the language compositions? The investigation addresses these questions through the deployment of the Metafunctions. Significantly, these processing tools assist in revealing the kind of Register of the advertising texts in terms of structural components and social treasures, influencing the communication domain. 


\section{METHODOLOGY}

\subsection{Sample/Participants}

The author with the support of Mrs. Bonke collected the print advertisements from the Punch newspaper as well as the Internet in the realm of the financial industry and fast moving consumer goods as probable domineering players in the Nigerian print advertisements. The relevance of the advertising texts to the study was the determiner of the choice of advertisements selected for analysis.

\subsection{Instrument(s)}

There are about thirty eight advertisements downloaded from the Internet through the computer as well as those snapped with a camera (Samsung WB50F). These were grouped into the spheres of their communicative relevance after which ten of the advertisements were selected for examination in order to determine their Register(s).

\subsection{Data collection procedures}

For a purpose of clarity, the study tabulates the textual patterns of the advertisements for analysis, as shown below, in Table 1.

\begin{tabular}{|c|c|c|}
\hline S/N & PRODUCT & TEXT \\
\hline 1 & Wema Bank $^{\circledR}$ & $\begin{array}{r}\text { //Introducing *945\#// Convenient banking has been in our genes since } \\
\text { 1945// Live the 945 life// bank the easy way.// }\end{array}$ \\
\hline 2 & Guinness $^{\circledR}$ & //Good things come to those who wait// \\
\hline 3 & Bournvita $^{\circledR}$ & //THE NEW BOURN IDENTITY// RESHAPED //\& REBOURN// \\
\hline 4 & Stanbic IBTC $^{\circledR}$ & $\begin{array}{c}\text { //Tomorrow's success rests on today's foundation// Happy Children's } \\
\text { Day from your one-stop financial partner// Moving Forward// }\end{array}$ \\
\hline 5 & Seven Up ${ }^{\circledR}$ & $\begin{array}{c}\text { /MHEN IT COMES TO COOL REFRESHING// THERE'S ONLY ONE } \\
\text { OGA AT THE TOP// THE DIFF IS CLEAR// }\end{array}$ \\
\hline 6 & Star $^{\circledR}$ & //The Shine Of Quality// \\
\hline 7 & Peak Milk & $\begin{array}{c}\text { //Make crispy chicken and other delicious meals using Peak Milk.// Buy } \\
\text { Peak Milk in Shoprite or Game Now!// Pecadomo// Peak can do more// }\end{array}$ \\
\hline 8 & Coca cola $^{\circledR}$ & //Share a Coke with...// \#shareaCokeNG// \\
\hline 9 & Gulder $^{\circledR}$ & /Mhen the barman is wasting time// \\
\hline 10 & Pepsi $^{\circledR}$ & //Refresh ur Rhythm// Bella naija// \\
\hline
\end{tabular}

Table 1: Register patterns of texts

Table 1 above represents the advertising texts presentation patterns with the introduction of slashes '//' as the indicator of text boundaries either as punctuated structure of a nominal group, compounding has tag or complete 
clause. Texts are reproduced, as appeared on the advertising plates, to display their registerial structures. The study utilizes Ideational, Interpersonal and Textual Metafunctions as analytical tools as observed in semiotic slots of Figure 2. The tripartite systemic analysis was translated to tables and graphs, in parallel with Maxwell (2013), Patton (2015), and Dalamu (2018b), in order to report the frequency of the communicative devices of the Metafunctions. Besides being evident, the evaluation strategy also allows readers to effortlessly perceive and understand the operation of Register facilities in their high, medium and low terms. In the tables, there are abbreviations, such as WB-T (Wema Bank Text), GN-T (Guinness Text), BR-T (Bournvita Text), SI-T (Stanbic IBTC Text), SU-T (Seven Up Text), ST-T (Star Text), PM-T (Peak Milk Text), CC-T (Coca cola Text), GD-T (Gulder Text) and PS-T (Pepsi Text), employed for space management. Thus, the discussion takes a course from the analysis.

\subsection{Data Analysis}

Figure 2, as shown below, is the application of Ideational, Interpersonal, and Textual Metafunctions on the advertising texts, representing their Register structures 
THE BUCKINGHAM JOURNAL OF LANGUAGE AND LINGUISTICS

VOLUME 102018

\begin{tabular}{|l|l|l|}
\hline Text la & Introducing & $* 945 \#$ \\
\hline Trans & Material & Goal \\
\hline \multirow{2}{*}{ Mood } & Predicator & Complement \\
\cline { 2 - 3 } & Residue \\
\hline Theme & Rheme \\
\hline
\end{tabular}

\begin{tabular}{|l|l|l|l|l|l|}
\hline Text $1 b$ & Convenient banking & has & been & in our gene & since 1945 \\
\hline Trans & Actor & Proc.: & Rel. Ident. & Circ.: Loc. & Circ.: Loc. \\
\hline \multirow{2}{*}{ Mood } & Subject & Finite & Predicator & Adjunct & Adjunct \\
\cline { 2 - 5 } & Mood & Residue & \\
\hline Theme & Theme & Rheme \\
\hline
\end{tabular}

\begin{tabular}{|c|c|c|c|}
\hline & Text $1 c$ & Live & the 945 life \\
\hline & Trans & Proc.: Material & \begin{tabular}{|l|} 
Goal \\
\end{tabular} \\
\hline & Mood & Predicator & Complement \\
\hline & & Residue & \\
\hline & Theme & Theme & Rheme \\
\hline
\end{tabular}

\begin{tabular}{|l|l|l|}
\hline Text $1 d$ & bank & the easy way. \\
\hline Trans & Proc.: Material & Goal \\
\hline Mood & Predicator & Complement \\
\cline { 2 - 3 } & Residue & Adjunct \\
\hline Theme & Theme & Rheme \\
\hline
\end{tabular}

\begin{tabular}{|l|l|l|l|l|}
\hline Text 2 & Good things & come to & those who wait \\
\hline Trans & Actor & Proc.: Material & Goal \\
\hline \multirow{2}{*}{ Mood } & Subject & present: Finite & come to: Predicator & Complement \\
\cline { 2 - 5 } & Mood & Residue & \\
\hline \multirow{2}{*}{\begin{tabular}{c} 
Theme \\
\cline { 2 - 5 }
\end{tabular}} & Theme & Rheme & \\
\hline
\end{tabular}

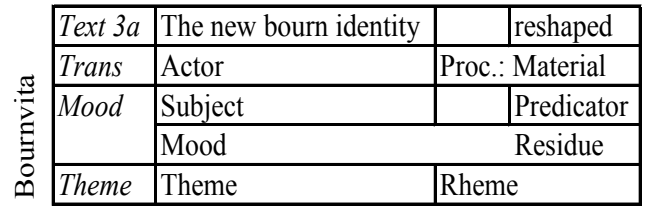

\begin{tabular}{|l|l|l|l|}
\hline Text $3 b$ & $\&$ & & rebourn \\
\hline Trans & Conj. & Proc.: Material \\
\hline \multirow{2}{*}{ Mood } & \multicolumn{2}{|l|}{} & Predicator \\
\cline { 2 - 3 } & Residue \\
\hline Theme & Rheme \\
\hline
\end{tabular}

\begin{tabular}{|c|c|c|c|c|}
\hline Text $4 a$ & Tomorrow's success & rests on & & today's foundation \\
\hline Trans & Behaver & Proc.: Behavic & & Range \\
\hline \multirow[t]{2}{*}{ Mood } & Subject & present: Finite & rest on: Predicator & Complement \\
\hline & Mood & & \multicolumn{2}{|l|}{ Residue } \\
\hline Theme & Theme & Rheme & & \\
\hline
\end{tabular}

\begin{tabular}{|c|c|c|c|}
\hline \multirow{2}{*}{\multicolumn{2}{|c|}{ 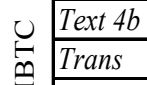 }} & Happy Children's Day & from your one-stop financial partner \\
\hline & & Minor Clause & Circ.: Location \\
\hline \multirow{2}{*}{\multicolumn{2}{|c|}{ Mood }} & \multirow[t]{2}{*}{ Minor Clause } & Adjunct \\
\hline & & & Residue \\
\hline & Theme & Theme & Rheme \\
\hline
\end{tabular}

\begin{tabular}{|l|l|l|}
\hline Text $4 c$ & Moving & Forward \\
\hline Trans & Proc.: Material & Goal \\
\hline Mood & Predicator & Compl. \\
\cline { 2 - 3 } & Residue \\
\hline Theme & Rheme \\
\hline
\end{tabular}




\begin{tabular}{|c|c|c|c|c|c|}
\hline Text $5 a$ & When & it & comes to & & cool refreshing \\
\hline Trans & Conj. & Actor & Proc.: Materia & & Goal \\
\hline \multirow[t]{2}{*}{ Mood } & & Subject & present: Finite & comes to: Predicator & Complement \\
\hline & & \multicolumn{2}{|l|}{ Mood } & Residue & \\
\hline Theme & Theme 1 & Theme 2 & Residue & & \\
\hline
\end{tabular}

\begin{tabular}{|l|l|l|l|l|l|}
\hline Text $5 b$ & There & 's & only & one oga & at the top \\
\hline Trans & & Proc.: Existential & Circ.: Manner & Existent & Circ.: Location \\
\hline \multirow{2}{*}{ Mood } & Subject & Finite & Adjunct & Complement & Adjunct \\
\cline { 2 - 5 } & Mood & Residue & \\
\hline Theme & Theme & Rheme & \\
\hline
\end{tabular}

\begin{tabular}{|c|c|c|c|c|}
\hline \multirow{4}{*}{$\begin{array}{l}2 \\
0\end{array}$} & Text $5 c$ & The diff & is & clear \\
\hline & Trans & Carrier & Proc.: Rel. attrib. & Attribute \\
\hline & Mood & Subject & Finite & Complement \\
\hline & & Mood & & Residue \\
\hline & Theme & Theme & Rheme & \\
\hline
\end{tabular}

\begin{tabular}{|l|l|l|}
\hline Text 6 & The shine & of quality \\
\hline Trans & Participant & Circ.: Cause \\
\hline Mood & Complement & Adjunct \\
\cline { 2 - 3 } & Residue \\
\hline \multirow{2}{*}{} & Theme & Rheme \\
\hline \multirow{2}{*}{}
\end{tabular}

\begin{tabular}{|l|l|l|}
\hline Text $7 a$ & Make & crispy chicken and other delicious meals using Peak Milk \\
\hline Trans & Proc.: Material & Goal \\
\hline \multirow{2}{*}{ Mood } & Predicator & Complement \\
\cline { 2 - 3 } & Residue \\
\hline Theme & Theme & Rheme \\
\hline
\end{tabular}

\begin{tabular}{|l|l|l|l|l|}
\hline Text $7 b$ & Buy & Peak Milk & in Shoprite or Game & Now! \\
\hline Trans & Proc.: Material & Goal & Circ.: Location & Circ.: Location \\
\hline Mood & Predicator & Complement & Adjunct & Adjunct \\
\cline { 2 - 5 } & Residue & Rheme & \\
\hline Theme & Theme & Rem & \\
\hline
\end{tabular}

\begin{tabular}{|l|l|}
\hline Text $7 c$ & Pecadomo \\
\hline Trans & Participant \\
\hline Mood & Complement \\
\cline { 2 - 3 } & Residue \\
\hline \multirow{3}{*}{} & \\
\hline Theme & Rheme \\
\hline
\end{tabular}

\begin{tabular}{|l|l|l|l|l|}
\hline Text 7d & Peak & can & do & more \\
\hline Trans & Actor & Proc.: Material & Goal \\
\hline \multirow{2}{*}{ Mood } & Subject & Finite & Predicator & Complement \\
\cline { 2 - 4 } & Mood & Residue \\
\hline Theme & Theme & Rheme \\
\hline
\end{tabular}


THE BUCKINGHAM JOURNAL OF LANGUAGE AND LINGUISTICS

VOLUME 102018

\begin{tabular}{|c|c|c|c|c|c|c|}
\hline \multirow{5}{*}{$\begin{array}{l}\frac{\pi}{8} \\
\text { ] }\end{array}$} & Text $8 a$ & Share & a Coke & with. & Text $8 b$ & \#shareacokeNG \\
\hline & Trans & Proc.: Material & Goal & Circ.: Accompaniment & Trans & Compound hashtag \\
\hline & Mood & Predicator & Complemen & Adjunct & Mood & Compound hashtag \\
\hline & & Residue & & & & \\
\hline & Theme & Theme & Rheme & & Theme & Compound hashtag \\
\hline
\end{tabular}

\begin{tabular}{|l|l|l|l|l|l|}
\hline Text 9 & When & the barman & is & wasting & time \\
\hline Trans & Conj. & Actor & Proc.: Material & Goal \\
\hline \multirow{2}{*}{$\bar{\Xi}$} & & Subject & Finite & Predicator & Complement \\
\cline { 3 - 6 } & & Mood & Residue & \\
\hline \multirow{2}{*}{} & & & & \\
\hline
\end{tabular}

\begin{tabular}{|c|c|c|c|c|}
\hline Text 10a & Refresh & ur rhythm & Text $10 b$ & Bella Naija \\
\hline \begin{tabular}{|l|} 
Trans \\
\end{tabular} & Proc.: Material & Goal & \begin{tabular}{|l|} 
Trans \\
\end{tabular} & Participant \\
\hline \multirow[t]{2}{*}{ Mood } & Predicator & Complement & \multirow[t]{2}{*}{ Mood } & Complement \\
\hline & Residue & & & \begin{tabular}{|l|} 
Residue \\
\end{tabular} \\
\hline Theme & Theme & Rheme & Theme & Rheme \\
\hline
\end{tabular}

Figure 2: Systemic analysis of advertising text

Transitivity, Mood and Theme have been the grammatical tools for processing the Register of the selected advertising texts of Wema Bank ${ }^{\circledR}$, Guinness $^{\circledR}$, Bournvita $^{\circledR}$, Stanbic IBTC ${ }^{\circledR}$, Seven Sp $^{\circledR}$, Star $^{\circledR}$, Peak $^{\circledR}$, Coca cola $^{\circledR}$, Gulder $^{\circledR}$, and $P e p s i^{\circledR}$. The applications are further translated to tables and graphs as instruments for computing the frequency of the structures.

\section{RESULTS}

The study evaluates the Register analysis in Figure 2 with tables and graphs indicated below in Figures 3, 4, 5 and 6. The goal of the outcome is to reveal the recurrence nature of the structural organizations of the advertising texts serving as the data of study.

\begin{tabular}{|c|c|c|c|c|c|c|c|c|c|c|c|c|c|c|c|c|c|c|c|c|}
\hline \multirow[t]{2}{*}{ Transitivity } & \multicolumn{3}{|c|}{ WB-T } & \multirow{2}{*}{\multicolumn{2}{|c|}{\begin{tabular}{|l|} 
GN-T \\
2
\end{tabular}}} & \multirow{2}{*}{\begin{tabular}{|l|l|} 
BR-T \\
$3 \mathrm{a}$ & $3 \mathrm{~b}$ \\
\end{tabular}} & \multicolumn{3}{|c|}{ SI-T } & \multicolumn{2}{|c|}{ SU-T } & \multirow{2}{*}{\multicolumn{2}{|c|}{\begin{tabular}{|l} 
ST-T \\
6
\end{tabular}}} & \multicolumn{3}{|c|}{ PM-T } & \multirow{2}{*}{\multicolumn{2}{|c|}{\begin{tabular}{|l|} 
CC-T \\
$8 \mathrm{a} / 8 \mathrm{~b}$
\end{tabular}}} & \multirow{2}{*}{\begin{tabular}{|l} 
GD-T \\
9
\end{tabular}} & \multirow{2}{*}{\begin{tabular}{|l} 
PS-T \\
10
\end{tabular}} \\
\hline & \begin{tabular}{|l|}
$1 \mathrm{a}$ \\
\end{tabular} & \begin{tabular}{l|l}
$1 \mathrm{~b}$ & 1 \\
\end{tabular} & \begin{tabular}{l|l}
$\mathrm{c}$ & 1 \\
\end{tabular} & & & & $\mathrm{~b} \mid 4 c$ & & $4 \mathrm{c}$ & $5 a$ & \begin{tabular}{|l|l}
$5 \mathrm{~b}$ & 5 \\
\end{tabular} & & & \begin{tabular}{|l|l}
$7 \mathrm{a}$ & 7 \\
\end{tabular} & \begin{tabular}{l|l|l}
$7 \mathrm{~b}$ & $7 \mathrm{c}$ \\
\end{tabular} & $7 \mathrm{~d}$ & & & & \\
\hline Material & 11 & \begin{tabular}{l|l}
0 & 1 \\
\end{tabular} & 1 & 1 & & \begin{tabular}{|l|l|}
1 & 1 \\
\end{tabular} & 0 & 0 & 1 & 1 & \begin{tabular}{|l|l|}
0 & 0 \\
\end{tabular} & \begin{tabular}{l|l|}
0 & 0 \\
\end{tabular} & & \begin{tabular}{|l|l|}
1 & 1 \\
\end{tabular} & \begin{tabular}{l|l}
1 & 0 \\
\end{tabular} & 1 & 1 & 0 & 1 & 1 \\
\hline Mental & 0 & 0 & 0 & 0 & & 0 & 0 & 0 & 0 & 0 & 0 & 0 & & 0 & 0 & 0 & 0 & 0 & 0 & 0 \\
\hline Relational & 1 & 0 & 0 & 0 & & 0 & 1 & 0 & 0 & $\overline{0}$ & 0 & 0 & & 0 & 0 & 0 & 0 & 0 & 0 & 0 \\
\hline Behavioral & 0 & 0 & 0 & 0 & & 0 & 0 & 0 & 0 & 0 & 0 & 0 & & 0 & 0 & 0 & 0 & 0 & 0 & 0 \\
\hline Verbal & 0 & 0 & 0 & 0 & & 0 & 0 & 0 & 0 & 0 & 0 & 0 & & 0 & 0 & 0 & 0 & 0 & 0 & 0 \\
\hline Existential & 0 & 0 & 0 & 0 & & 0 & 0 & 0 & 0 & 0 & 1 & 0 & & 0 & 0 & 0 & 0 & 0 & 0 & 0 \\
\hline Circumstance & 0 & 2 & T0 & 0 & & \begin{tabular}{l|l|}
0 & 0 \\
\end{tabular} & 1 & 0 & 0 & 0 & \begin{tabular}{|l|l|}
2 & 0 \\
\end{tabular} & 1 & & \begin{tabular}{|l|l|}
0 & 0 \\
\end{tabular} & 0 & 0 & & 0 & 0 & 0 \\
\hline
\end{tabular}

Table 2: Computation of Transitivity elements 


\begin{tabular}{|l|l|}
\hline Transitivity & Frequency \\
\hline Material & 14 \\
\hline Mental & 0 \\
\hline Relational & 3 \\
\hline Behavioral & 0 \\
\hline Verbal & 0 \\
\hline Existential & 1 \\
\hline Circumstance & 9 \\
\hline
\end{tabular}

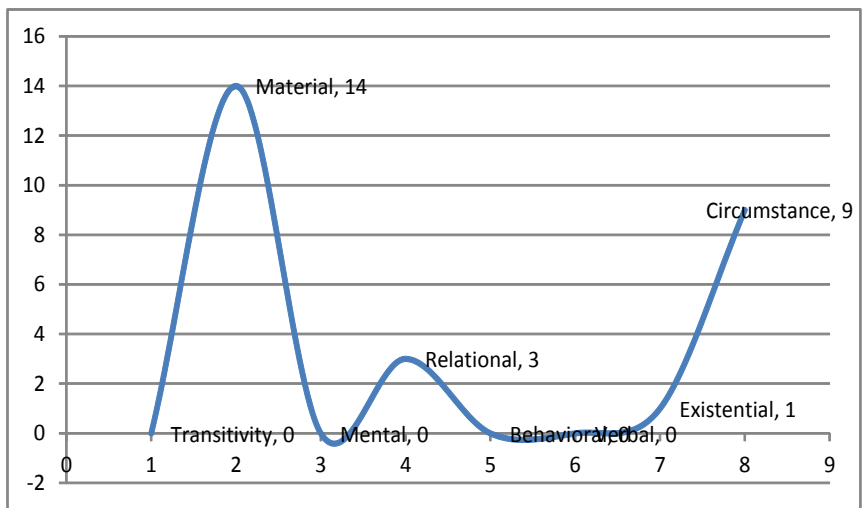

Figure 3: Frequency of transitivity system

The transitivity system assessment in Figure 3 demonstrates that Material Process operates more often than any other elements for 14 times. Besides that, Relational and Existential Processes functions three and one times respectively. Figure 3 reports further that the Circumstance, which adds some communicative values to the Transitivity ascertains its function to be nine times. The account shows that a call of the target audience to action from the copywriters plays a domineering role in the entire management augmented with some textual additives.

\begin{tabular}{|c|c|c|c|c|c|c|c|c|c|c|c|c|c|c|c|c|c|c|c|c|c|c|}
\hline \multirow[t]{2}{*}{ Mood } & \multicolumn{4}{|c|}{ WB-T } & \multirow{2}{*}{\begin{tabular}{|l} 
GN-T \\
2 \\
\end{tabular}} & \multicolumn{2}{|c|}{ BR-T } & \multicolumn{3}{|c|}{ SI-T } & \multicolumn{3}{|c|}{ SU-T } & \multirow{2}{*}{\begin{tabular}{|l|} 
ST-T \\
6 \\
\end{tabular}} & \multicolumn{4}{|c|}{ PM-T } & \multicolumn{2}{|c|}{ CC-T } & \multirow{2}{*}{\begin{tabular}{|l|} 
GD-T \\
9 \\
\end{tabular}} & \multirow{2}{*}{\begin{tabular}{|l} 
PS-T \\
10 \\
\end{tabular}} \\
\hline & $1 \mathrm{a}$ & $1 \mathrm{~b}$ & $1 \mathrm{c}$ & $1 \mathrm{~d}$ & & $3 \mathrm{a}$ & \begin{tabular}{|l|l}
$3 \mathrm{~b}$ & 2 \\
\end{tabular} & $4 \mathrm{a}$ & \begin{tabular}{l|l}
$4 \mathrm{~b}$ & 4 \\
\end{tabular} & $4 \mathrm{c}$ & $5 \mathrm{a}$ & \begin{tabular}{l|l}
$5 b$ & 5 \\
\end{tabular} & \begin{tabular}{l|l}
$5 \mathrm{c}$ & 6 \\
\end{tabular} & & $7 \mathrm{a}$ & $7 \mathrm{~b}$ & $7 \mathrm{c}$ & $7 \mathrm{~d} / 8$ & \begin{tabular}{l|l}
$8 \mathrm{a}$ & 8 \\
\end{tabular} & $8 \mathrm{~b}$ & & \\
\hline Subject & 0 & 1 & 0 & \begin{tabular}{l|l}
0 \\
\end{tabular} & 1 & 1 & \begin{tabular}{l|l}
0 & 1 \\
\end{tabular} & \begin{tabular}{l|l}
1 & \\
\end{tabular} & \begin{tabular}{l|l}
0 & 0 \\
\end{tabular} & 0 & 1 & \begin{tabular}{l|l}
1 & 1 \\
\end{tabular} & \begin{tabular}{l|l}
1 & 0 \\
\end{tabular} & 0 & 0 & \begin{tabular}{l|l}
0 & ( \\
\end{tabular} & 0 & \begin{tabular}{l|l}
1 & 0 \\
\end{tabular} & \begin{tabular}{l|l}
0 & 0 \\
\end{tabular} & 0 & 1 & 0 \\
\hline Finite & 1 & 0 & 0 & 0 & 1 & 0 & 0 & 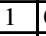 & 0 & 0 & 1 & 1 & 1 & 0 & 0 & 0 & 0 & 1 & 0 & 0 & & 0 \\
\hline Predic & 1 & 1 & 1 & 1 & 0 & 1 & 1 & 1 & 0 & 1 & 1 & 0 & 0 & 0 & 1 & 1 & 0 & 1 & 1 & 0 & 1 & 1 \\
\hline Con & 1 & 0 & 1 & 1 & 1 & 0 & 0 & 1 & 0 & 1 & 1 & 0 & 1 & 0 & 1 & 1 & 1 & 1 & 1 & & 1 & 2 \\
\hline Adjunct & 0 & 2 & 0 & 0 & 0 & 0 & 0 & 0 & 1 & 0 & 0 & 2 & 0 & 1 & 0 & 2 & 0 & 0 & 1 & ) & 0 & 0 \\
\hline
\end{tabular}

Table 3: Computation of Mood elements

\begin{tabular}{|l|l|}
\hline Mood & Frequency \\
\hline Subject & 9 \\
\hline Finite & 8 \\
\hline Predicator & 15 \\
\hline Complement & 16 \\
\hline Adjunct & 9 \\
\hline
\end{tabular}

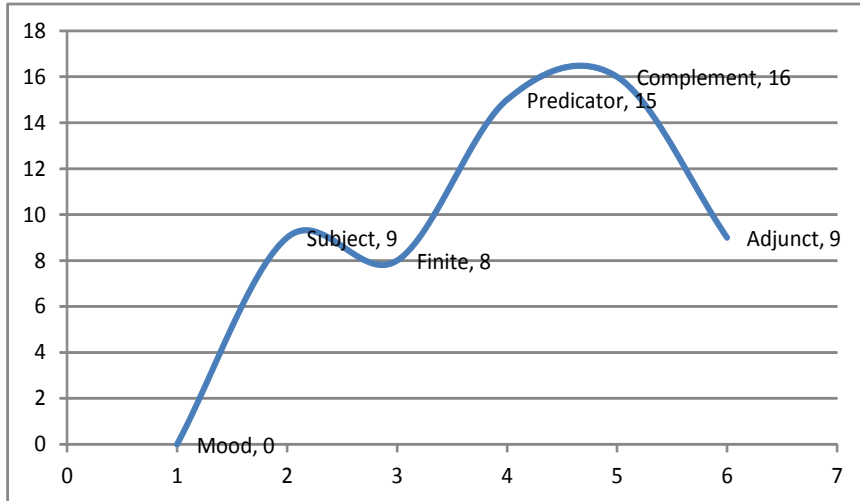

Figure 4: Frequency of mood system 
It is evident in Figure 4 that in the mood system Complement and Predicator have the highest values of 16 and 15 in the analysis. Subject and Adjunct function about nine times each whereas Finite recurs only eight times. Then, the examination reckons that Complement and Predicator occupy prominent positions of the textual messages while Subject, Adjunct and Finite are seemingly of similar levels. By implication, apart from the contents of the persuasive information, advertisers modify their messages with additional facilities of enhancement.

\begin{tabular}{|c|c|c|c|c|c|c|c|c|c|c|c|c|c|c|c|c|c|c|c|c|c|c|}
\hline \multirow[t]{2}{*}{ Theme } & \multicolumn{4}{|c|}{ WB-T } & \multirow{2}{*}{\begin{tabular}{|l|} 
GN-T \\
2 \\
\end{tabular}} & \multicolumn{2}{|c|}{ BR-T } & \multicolumn{3}{|c|}{ SI-T } & \multicolumn{3}{|c|}{ SU-T } & \multirow{2}{*}{\begin{tabular}{|l|} 
ST-T \\
6 \\
\end{tabular}} & \multicolumn{4}{|c|}{ PM-T } & \multicolumn{2}{|c|}{ CC-T } & \multirow{2}{*}{\begin{tabular}{|l} 
GD-T \\
9 \\
\end{tabular}} & \multirow{2}{*}{$\begin{array}{l}\text { PS-T } \\
10 \\
\end{array}$} \\
\hline & $1 \mathrm{a}$ & $1 \mathrm{~b}$ & $1 \mathrm{c}$ & $1 \mathrm{~d}$ & & $3 a$ & $3 b$ & $4 a$ & $4 \mathrm{~b}$ & $4 \mathrm{c}$ & $5 a$ & $5 b$ & $5 c$ & & $7 a$ & $7 \mathrm{~b}$ & $7 \mathrm{c}$ & $7 \mathrm{~d}$ & $8 a$ & $8 \mathrm{~b}$ & & \\
\hline Theme 1 & 0 & 0 & 0 & 0 & 0 & 0 & 0 & 0 & 0 & 0 & 1 & 0 & 0 & 0 & 0 & 0 & 0 & 0 & 0 & 0 & 1 & 0 \\
\hline Theme 2 & 1 & 1 & 1 & 1 & 1 & 1 & 0 & 1 & 1 & 0 & 1 & 1 & 1 & 0 & 1 & 1 & 0 & 1 & 1 & 0 & 1 & 1 \\
\hline Rheme & 1 & 1 & 1 & 1 & 1 & 1 & 1 & 1 & 1 & 1 & 1 & 1 & 1 & 1 & 1 & 1 & 1 & 1 & 1 & 0 & 1 & 1 \\
\hline
\end{tabular}

Table 4: Computation of thematic elements

\begin{tabular}{|l|l|}
\hline Theme & Frequency \\
\hline Theme 1 & 2 \\
\hline Theme 2 & 17 \\
\hline Rheme & 21 \\
\hline
\end{tabular}

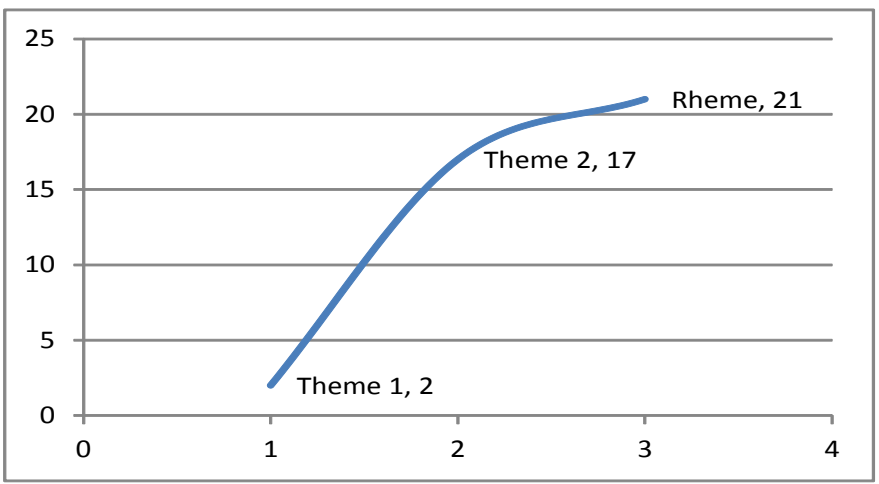

Figure 5: Frequency of thematic system

A critical observation of the thematic system in Figure 5 exhibits that the Rheme functions in a higher capacity in the investigation with an estimate value of 21 times. The calibration also indicates Theme 2 as it operates 17 consecutive times in the Register analysis. Theme 1 recurs only two times in the chart. As computed, it shows that the rhematic sphere accommodates the messages of the advertisements. 


\begin{tabular}{|c|c|c|c|c|c|c|c|c|c|c|c|c|c|c|c|}
\hline \multirow[t]{2}{*}{ Metafunction } & \multicolumn{15}{|c|}{ Frequency Domain } \\
\hline & 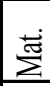 & 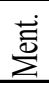 & $\vec{Q}$ & 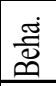 & $\stackrel{\dot{0}}{\dot{0}}$ & $\begin{array}{l}. \dot{m} \\
. \dot{x} \\
\\
\end{array}$ & 氖 & $\dot{\vec{D}}$ & 主 & $\begin{array}{l}\vec{D} \\
\text { ¿ }\end{array}$ & 家 & 莺 & $\begin{array}{l}\vec{\Phi} \\
E\end{array}$ & $\begin{array}{l}\stackrel{\text { o }}{E} \\
\text { E }\end{array}$ & $\frac{\dot{E}}{\tilde{a}}$ \\
\hline Transitivity & 14 & 0 & 3 & 0 & 0 & 1 & 9 & 0 & 0 & 0 & 0 & 0 & 0 & 0 & 0 \\
\hline Mood & 0 & 0 & 0 & 0 & 0 & 0 & 0 & 9 & 8 & 15 & 16 & 9 & 0 & 0 & 0 \\
\hline Theme & 0 & 0 & 0 & 0 & 0 & 0 & 0 & 0 & 0 & 0 & 0 & 0 & 2 & 17 & 21 \\
\hline
\end{tabular}

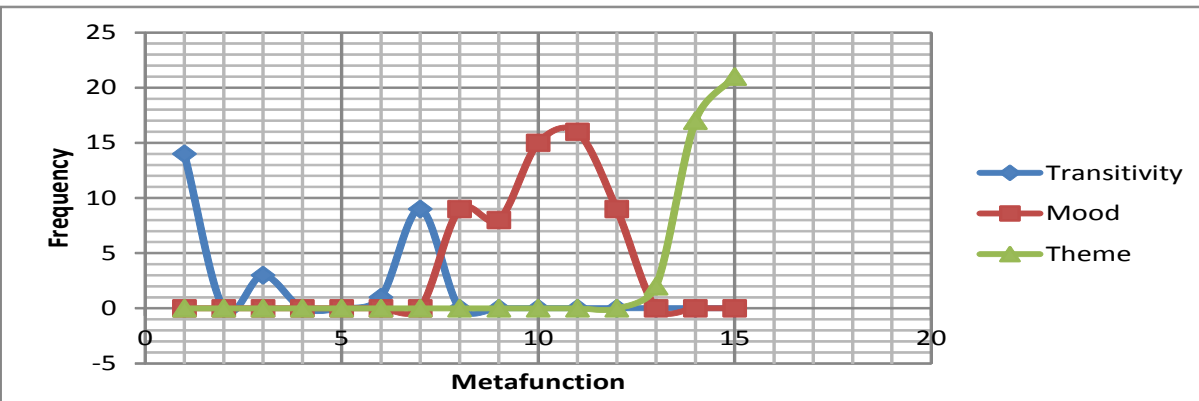

Figure 6: The flow of Register devices in the advertisements

Figure 6 illustrates the flow of the frequency of the three Metafunctions in their various grammatical variations of Transitivity, Mood and Theme. The assessment demonstrates Material Process and Circumstance as most functioning devices on the transitivity system; Complement and Predicator as the elements deployed to achieve the mood system; as Rheme and Theme are well utilized in the thematic system of the clauses. These are the core of the Register devices of the advertising texts. One could recapitulate, as revealed in Figure 6, that Rheme and Theme are devices of the Metafunctions that the advertisers employed to influence the decisions of recipients. Quickly, therefore, the Register appearance is a revelation that in every socio-cultural communication the textual constructs are foregrounded in certain ways in which the entire human behaviors take a course. A similar reaction is what the analyst has observed in the Register facilities of the evaluated advertisements.

\section{DISCUSSION}

The study has revealed Register as a concept operating in two planes. That is the planes of language and its social environment. As earlier stated, the Metafunctions have assisted in assessing the features of texts as shown in Figure 1. On that ground, the discussion framework has expounded the nature of the clauses of the advertisements in terms of grammatical structures, textual organizations, and content meanings. For semantic motives, the writer has interconnected the systemic menus with the context of situation's norms of Field, Tenor and Mode in a discourse enterprise. One could also point out that the texts considered are all written in advertisements' frames, which serve as 
the interface between the commodity and the public without probable feedback.

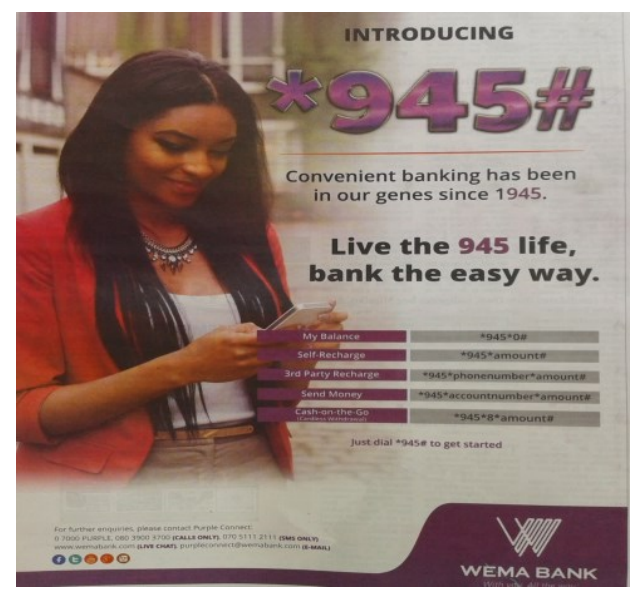

Text 1

The advertisement of Wema Bank ${ }^{\circledR}$ contains four clauses. These are: Introducing *945\#; Convenient banking has been in our gene since 1945; Live the life of 945 life; and Bank the easy way. As analyzed in Figure 2, 1a is a fragmented declarative; $1 \mathrm{~b}$ is a full declarative; $1 \mathrm{c}$ and $1 \mathrm{~d}$ are imperative clauses. It implies that the messages oscillate between open statements and commands. Apart from the declarative in $1 \mathrm{~b}$ with the Finite, has, to sensitize readers about a banking system that began in 1945 till the present, none of the clauses are relevant in time factor. One could also observe the pertinence of the clause background here where Text $1 \mathrm{~b}, 1 \mathrm{c}$, and $1 \mathrm{~d}$ function thematically, leaving 1a without the Theme. However, Material Processes dominate the rhematic field. They are: Introducing, Live and Bank. The advertiser deploys the Predicator, Introducing that serves as the Material Process to achieve two things. It serves as an announcement to consumers as well as recommending *945\# to them as a new module of banking suitable in practice and time. The benefit to be derived from the novel system might have influenced Wema Bank to proclaim its existence with has been in order to create confidence on the audience.

Live sensitizes readers to form a permanent habit with the Goal, the 945 life. In the point of view of the advertiser, persevering in the 945 life is a means of surviving in the banking system. That claim seems to further stimulate recipients to Bank the easy way. It means that Wema Bank has created a comfortable system of transactions for consumers, where none will experience a sort of impediment or difficulty. The 945 package is casual because it permits clients to relax while doing their transactions. The Register, *945\#, is striking from some perspectives. It is a referent of Wema Bank constructed from the date of its establishment indicated through the circumstance of location, since 1945 . $* 94$ \# has a morphological influence in 
the sense that the digit, 1 , is fragmented (Cook, 2001; Dalamu, 2018c) from 1945 to produce 945 . And the introduction of * and \# around 945 allows for the banking product of $* 945 \#$. The new concept is fascinating that is a probable motive for the argument that $* 945 \#$ is in our gene. This refers that *945\# is hereditary. In a sense, it is predetermined because the principle is a derivative of the 'Fathers of Wema Bank.' In addition, *945\# is a computerized Register code that connects users to the database of the bank, permitting them to conduct financial business online through the mobile telephone.

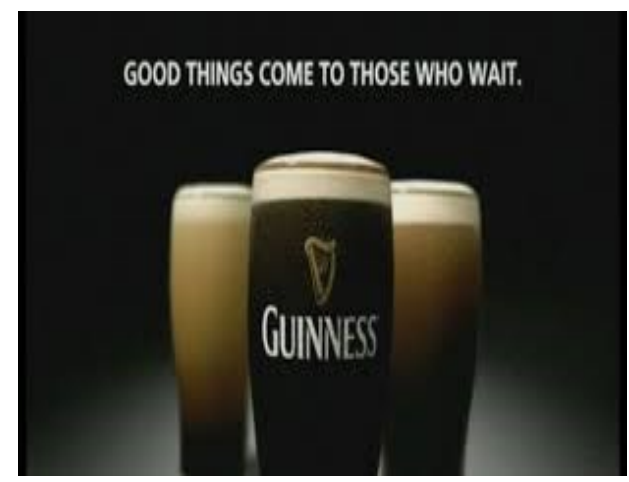

Text 2

The Guinness ${ }^{\circledR}$ advertisement exhibits a declarative clause. That is, Good things come to those who wait. The mood components function in the domains of Subject, Finite, Predicator and Complement. The verbal group is salient because come to as a content component operates as both Finite in its present form and Predicator. The distribution illustrates the sensitivity of SFL to explaining a 'fused' verbal element of a clause (Halliday \& Matthiessen, 2004). The point of departure of the clause is Good things. The Theme introduces the clause from the point of Subject, revealing the Actor in the message. The Predicator, come to, is a phrasal verb serving at the same time as the Material Process of the transitivity system. The Process, come to, excites recipients to patience in all their actions. This is a call not only to devote one's personal life to acting on an event; it is also an incitement and an assurance that Good things will naturally manifest at the culmination of one's efforts. The construct is sermonized as well as poetic. The encouragement becomes imperative on the basis that Guinness, as suggested, represents a precious thing. Perhaps, it takes the brewers some patience and fixed resolution deliberately confined to before they can produce Guinness stout that is worthy of note today, bearing in mind that the product came to market in 1759 (The Guinness \& Guinness Storehouse, n.d.). The classification of Guinness as phenomenal is time bound. The poet-preacher-advertiser persuades readers to reach a compromise with their attitudes toward any 
desire and 'hold their breath' to arrive at accommodating patience. The Goals, those who wait, Guinness counsels, are great achievers in life.

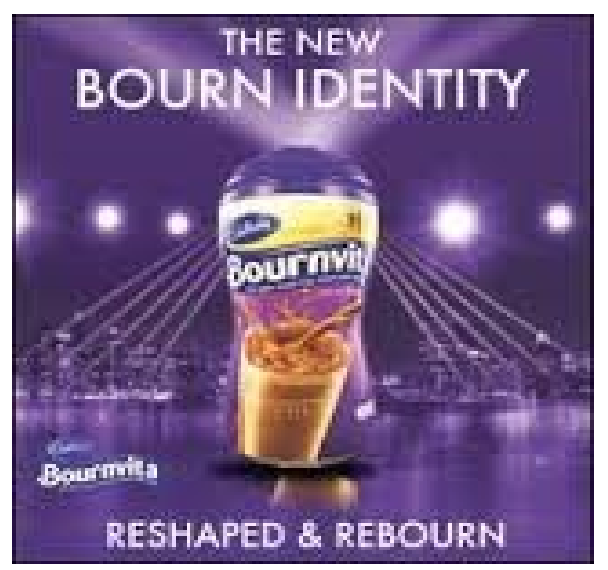

Text 3

The study positions the scattered Register of Text 3 into two declarative clauses of The new bourn identity...reshaped, and \& rebourn. Given those structural circumstances, the Finite, which one might suggest as is, is fragmented as a means of eliciting readers to textual economy and memorability (Leech, 1966; Vestergard \& Schroder, 1985). Text 3a orientates recipients with Theme, The new bourn identities unlike $3 \mathrm{~b}$ with only Rheme that is, \& rebourn. Bournvita ${ }^{\circledR}$ is the only participant in the two punctuated clause, personified as a living organism. The utilization of the Register facility, bourn, is a pointer to that incredible remark. Bourn, a clip from Bournvita. The text replicates bourn as an activity of giving life to a new baby. Projecting Bournvita as a large omnivorous mammalian being is just a matter of interchangeability (Williamson, 1978) to produce a stimulating effect that has the capacity to woo and win readers to patronize the commodity. The Material Processes of reshaped and rebourn promote Bournvita as a 'born again' entity, yielding a kind of consumption rebirth. That means Bournvita is an old beverage with new characteristics in terms of physical appearance and internal content. The advertiser based the selling strategy on these to lure readers to buy Bournvita. The reorganization endeavor informs the new look of the beverage. 


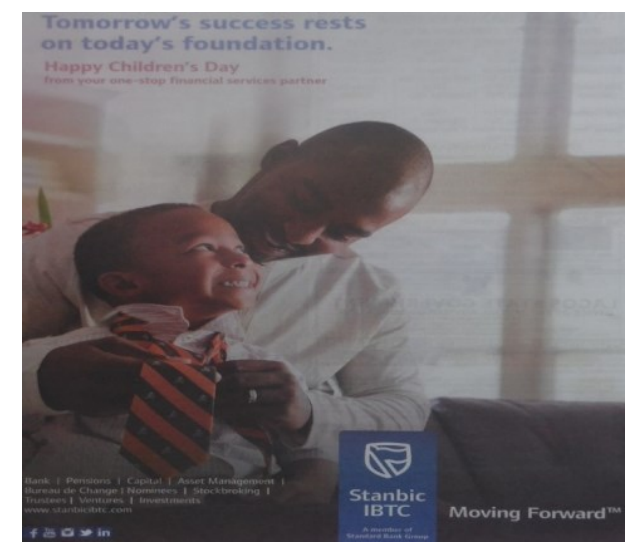

Text 4

Text 4 patronizes three grammatical gains of different perspectives. The first clause is declarative, that is, Tomorrow' success rests on today's foundation. The second is a minor clause indicating as Happy Children's Day from your one-stop financial partner. Moving Forward is the third clause, operating as a chopped up structural facility. The declarative in $4 \mathrm{a}$ has its dominion in Mood and Residue with a shared verbal group of rests on into Finite (present) and Predicator (rest on). The thematic order of connection begins with Tomorrow's success in 4a and Happy Children's Day in 4b, whereas, $4 \mathrm{c}$ operates on Rheme. It means that $4 \mathrm{c}$ manifests in only the Predicator and Complement communicative devices. As $4 \mathrm{~b}$ is a minor clause without a Process, $4 \mathrm{a}$ and $4 \mathrm{c}$ reveal their Processes as rests on - Behavioral, and Moving - Material. The phrasal verb, rests on, creates a sense of quietness as well as relaxation of the information of the clause.

That points to peace, freedom, and tranquility from anxieties and worries of life. The statement refers that if parents and guardians could establish children in the right path of life today the children will surely witness stillness in their future well-being. Stanbic IBTC ${ }^{\circledR}$ deploys children ideology to convince parents of the bank's concern for future leaders. Such behavior could excite parents to patronize the financial institution. Happy Children's Day is a minor clause not seriously analyzable (Dalamu, 2018d), nonetheless, the supported Adjunct, from your one-stop financial partner exhibits some analytical significance. From your one-stop financial partner is a circumstantial element that informs recipients of the advertisement about the source of the message. The circumstance is locative referring to the Stanbic $I B T C$ workforce. When the Material Process of Move runs along with Forward, it appears that the two entities operate as an idiomatic expression. Thus, Moving Forward, in the view of the bank operators, projects the institution as a progressive body practicing modernized methodology. 


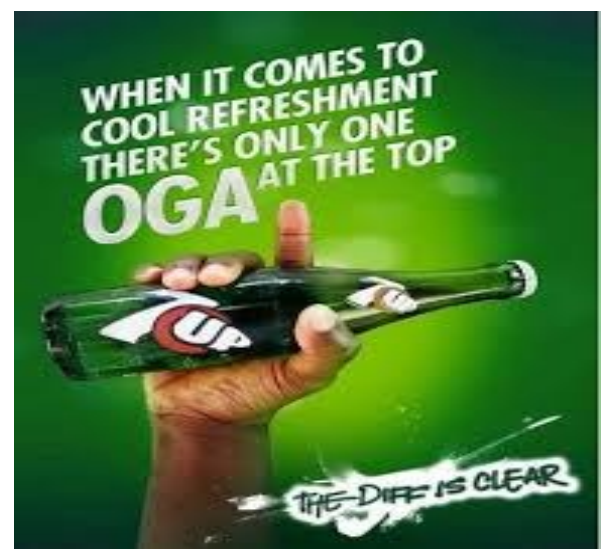

Text 5

The Seven $U p^{\circledR}$ text contains a complex and simple clauses of When it comes to cool refreshing there's only one Oga at the top and The diff is clear. The complex clause as in 5a and $5 \mathrm{~b}$ has When as the link between them. When is a hypotactic element binding the clauses together as a unit (Thompson, 2014). Apart from that, the three simple clauses are declaratives making some statements to readers about Seven Up soft drink. The appearances of the structures allow for the kernels of the Metafunctions to be obvious in them. The mood system operates Subject-Finite organs in the clauses, as the Processes function in the entire organization of the clauses. Clause 5a creates suspense in which $5 \mathrm{~b}$ serves as a relief. The point of departure of $5 \mathrm{a}$ is unlike $5 \mathrm{~b}$ and $5 \mathrm{c}$ because it contains When as Theme 1 and it as Theme 2. When and it function as Textual Theme and Ideational Theme respectively. One could realize three different Processes in the text as communicative content Register(s). These are: comes to - Material Process: ' $s$ - Existential Process; and is - Relational Attributive Process. As earlier discussed, comes to, as a unit, reaches a conclusion (this time) on personal satisfaction. There and 's go together in SFL as linguistic devices of Existential Process, referring to a certain event. There's points to Seven Up as one $O g a$ at the echelon of the soft drink category. The degree of the position that Seven Up occupies is augmented with a circumstance of manner, only.

The deployment of $O g a$ (a boss) is noteworthy because it is a Yorùbá (a Nigerian language in the South West) lexicon intrudes into an English clause. The Register, $O g a$, in the clause is contextual as a code-mixing entity showing a structural relationship between English and Yorùbá (Dalamu, 2017a). It also in displays the acceptability of $O g a$ as a universal terminology in communicative exchanges among Nigerians irrespective of tribes and tongues. The argument is based on the fact that the advertisement is neither for Yorùbá nor English speakers alone. The Seven Up advertisement focuses on the entire public space. At the top is a circumstance of location, pointing to 
Oga as a referent of Seven Up. There is a difference in the 's in $5 \mathrm{~b}$ and is in $5 \mathrm{c}$. The element is in $5 \mathrm{c}$ is Relational unlike the Existential device in $5 \mathrm{~b}$, the Carrier, The diff and Attribute, clear, qualifying it, which illustrates that. It is also nice to state that diff is clipped from difference. This is a way of the advertiser's utilization of the poetic license (Xhignesse, 2016). One could also observe the textual freedom in cool refreshing as the Goal of the Process. It is a case of misuse of priority in the field of collocation. Refreshing seems not to accept the Classifier cool (Okoro, 2008). The variegated Register facilities in the Seven Up texts are to ensure that readers surrender to the sensitization tactic.

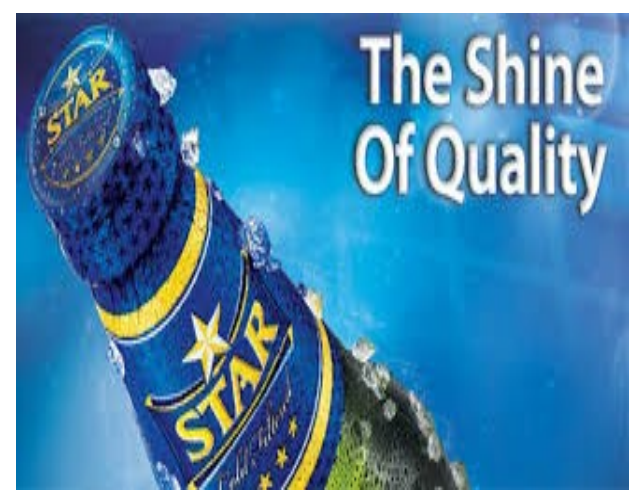

Text 6

The elements of nominal group (NG) surround the Register in Text 6 . The NG is The shine of quality. The appearance of the structure poses a constraint to either classifying the disjunctive grammar into clauses or pinpointing the nature of its transitivity system. Nevertheless, the NG, from the point of view of Interpersonal Metafunction, possesses both Complement - The shine and Adjunct - of quality. The reason is that, the study classifies the NG as operating in the domain of Residue. In that case, The shine of quality is also a rhematic device. In a systemic manner, The shine is Head of NG with a prepositional phrase of of quality, serving as qualifier. In the NG distribution, two things could be deduced as Transitivity facilities despite the challenge that the disjunctive structure constitutes on the analysis. These are: The shine as Participant and of quality as a circumstantial device of cause. The persuasion in the punctuated structure is that Star lager beer is an embodiment of excellent features. Perhaps, the idea is connected to the sparkling quality of the beer that could be of good worth. The manufacturing process of Star, in the perspective of the copywriter, makes it suitable for an exalted social position in the beer market. So, The shine of quality is deployed as an attractive linguistic organ in order to achieve the target of consumption. 


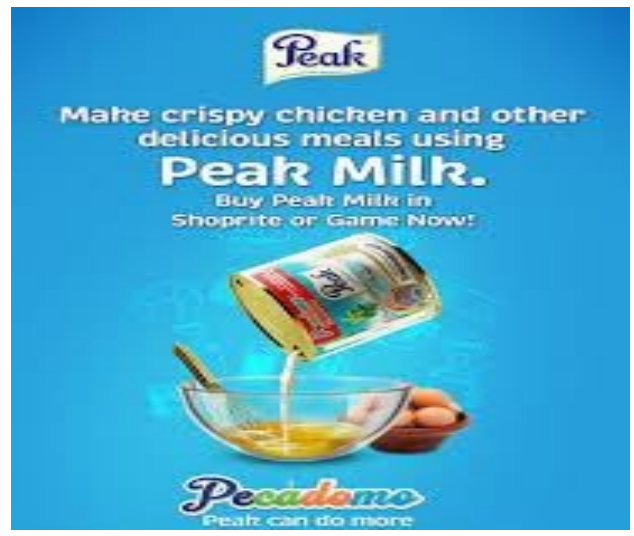

\section{Text 7}

There are four constructs in Text 7. Out of these are two imperative clauses - Make crispy and other delicious meals using Peak Milk and Buy Peak Milk in Shoprite or Game! There is neologism - Pecadomo as well as a declarative, that is, Peak can do more. Make and Buy are Predicators of imperatives operating at the same time as Themes for the clauses (Dalamu, 2017e). Although, Predicators and Complements are common factors in the imperative clauses of $7 \mathrm{a}$ and $7 \mathrm{~b}, 7 \mathrm{~b}$ advances by adding two circumstantial Adjunct of in Shoprite or Game and Now as contributors to the message. The circumstances disclose to readers location in place and time where Peak can be purchased. The Material Process, Make, sensitizes consumers to proceed to utilize Peak Milk in the preparation of crispy and other delicious meals. The advertiser, however, explains that using Peak Milk costs a fortune. That is the basis for introducing the imperative in $7 \mathrm{~b}$ with a command-marker. That is, Buy. The Material Process, Buy, indicates that the consumption of Peak Milk attracts cash exchange and not free of charge. In that sense, the advertisement directs readers to Shoprite or Game where Peak Milk can be obtained with immediate effect.

Clauses $7 \mathrm{c}$ and $7 \mathrm{~d}$ are two of a kind communicative facility because $7 \mathrm{c}$ is a declarative of $7 \mathrm{~d}$. This refers that Pecadomo has its origin from Peak can do more. For the fact that Pecadomo has fundamental neologism reality, the author classifies the lexicon as Participant, Complement and Rheme in the spheres of Metafunctions. It is significant to bear in mind that Pecadomo is an emblem of Peak Milk for now. It is sustained in the 'persuasive dictionary' of Friesland Foods ${ }^{\circledR}$. By implication, the word formation process, expressed as Pecadomo, is astonishing compounding. Thus, it is a compatible combination of compounding, coinage and blending (Yule, 1996; Adams, 2001; Bauer, 2001; Booij, 2007; Zapata, 2007; Dalamu, 2018e). In the domain of the lexemic formation, Peak can do more projects Peak as Actor that has the ability to perform beyond the expectation of consumers. The Material Process, can $d o$, as a syntactic marker of declarative, exemplifies the argument, further 
emphasizing the degree of performance of Peak Milk in the human body. The Goal, more, serves a comparison purpose. The copywriter deploys more either as comparing the past contributions of the product to the body with its present contribution or as weighing in a balance what Peak offers consumers with other milk products in the market space. The competition in the global market could have informed the employment of more. More importantly, it is very salient to observe that Peak is referenced four times in the communication. That means each clause contains an element of Peak. That is quite emphatic for repetition assists the effectiveness of advertising messages in the memories of the target audience (Geis, 1982; Packard, 2007; Ogilvy, 2013). The emphasis is obvious as it goes to an extent of coining a lexeme Pecadomo for the milk as demonstrated in clause $7 \mathrm{c}$.

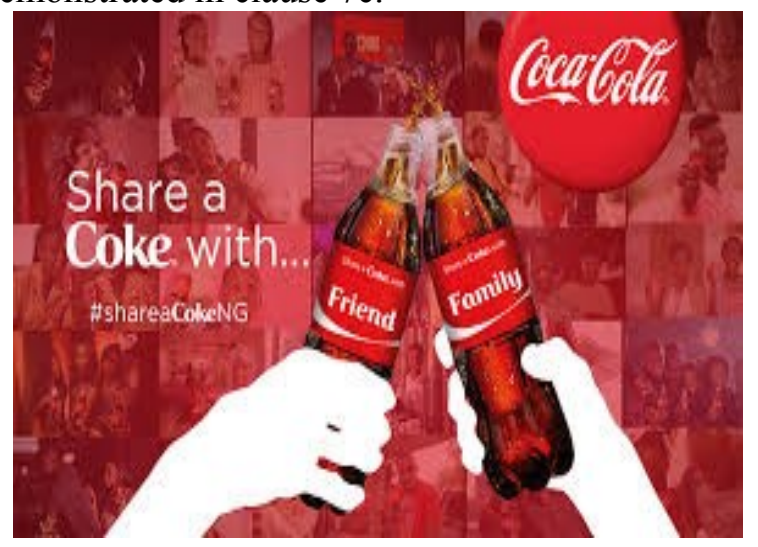

Text 8

In Text 8a, Share a Coke with... is imperative constructed as suspense. The Adjunct, with..., signifies that. The Predicator, Share, is accomplished with Complement, a Coke. It is in that regard that Share operates as the point of departure of the clause. The command persuades readers to shun selfishness but rather to adopt a spirit of giving. The transitivity system also connects to the information through the Material Process of Share, Goal $-a$ Coke, and with... as a circumstance of accompaniment, as earlier mentioned, expressing what could be called unpleasant emotion of apprehension. The message creates anticipation to a particular climax, in which the inscription of Friends and Family on the labels of Coke bottle serves as the relief. The construction of the anxiety with (...) creates excitement for the consumption of Coke. The Process, Share, influences recipients to a spirit of distributorship where a Coke, according to the advertiser, must be dispensed in several portions to relatives and well-wishers. Indirectly, the advertisement sensitizes consumers to love one another without dissimulation. In the real sense of the information, disseminating one's allotment of Coke to others does not only signify affection; it rather influences the sales of the product en masse. The more the contents are evenly distributed among the people the better the 
purchase of Coke. The copywriter understands that to have urged consumers to Share a Coke with the people around them. Text 8a \#shareacokeNG is a hash tag signaling a support for the message. The sharp sign, as it appears, focuses on the Nigerian people with the label of $N G$ as preceded in the metadata tag or octothorpe. The number sign, \#, is primarily of generative phonology (Chomsky \& Halle, 1968) as a means of indicating boundaries in relation to phonemes, morphemes, words and phrases (Yallop \& Clark, 2006, p. 133-147).

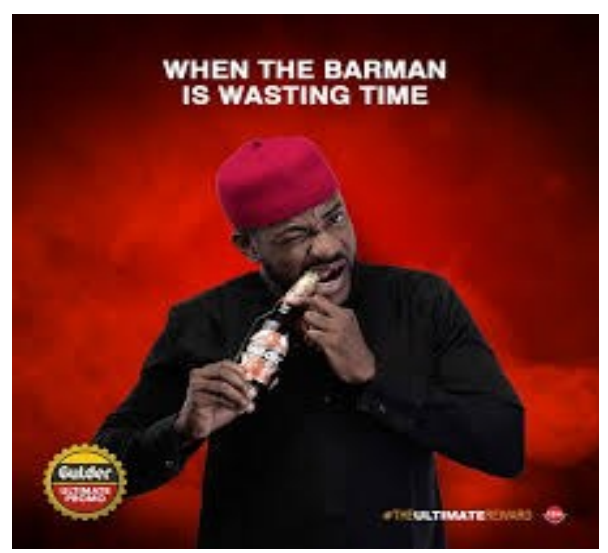

Text 9

The clause, When the barman is wasting time in Text 9, is an incomplete structure most especially with the introduction of When. Although, it is declarative, the second-half of it is punctuated. The action of the man in the advertising plate reveals the expectation of the advertisers from readers. It means that the text must be read together for a complete meaning deduction. In that sense, the text and image contribute equally to the advertisement's semantic implications. The text-cum-image relationship is relayed (Vestergaard \& Schroder, 1985; Forceville, 1996). Thus, When the barman is wasting time, the image argues, a consumer of Gulder $^{\circledR}$ must use his/her teeth to open the beer. The message of the text is very fascinating. It refers to a kind of addiction that the consumer must have for the consumption of Gulder, the ultimate, as rightly labeled. The sensitization creates the consumer a thirst for Gulder. And perhaps, the consumer perceives the drinking of Gulder as a rare opportunity that one needs to seize, when an individual craves for enjoyment.

When is a Conjunction in the domain of hypotactic, as earlier stated, functioning to bind two clauses together to produce a complex entity (Halliday \& Matthiessen, 2014). Now that readers are kept in suspense of the supposed simple clause, the available declarative has the barman as Subject with $i s$ operating as Finite, revealing time in its present continuous status. The tense is fully understood with wasting acting as Predicator. The availability of Conjunction, When, influences the clause arrangement to have Textual Theme 
as well as Ideational Theme of the barman. As a result, the Transitivity interprets is wasting as the Material Process demonstrating devastation, destruction and squandering of available resources. The Goal, time, reveals to consumers the kind of resources undergoing devastation. So, the advertiser suggests to recipients that the barman spends time idly, perhaps, by doing something irrelevant to his/her goal in the pub. As a result, a consumer must act fast to satisfy the individual's craving. That is, a sensation of the throat's dryness.

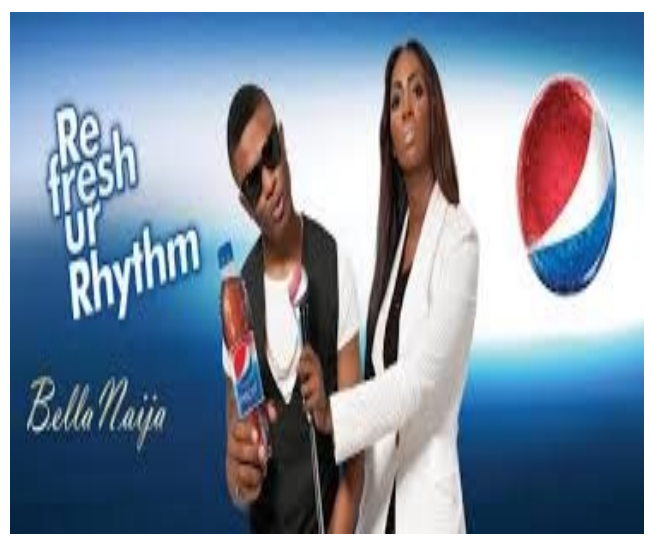

Text 10

The two texts in $10 \mathrm{a}$ and $10 \mathrm{~b}$ are imperative and nominal group respectively. The imperative, Refresh ur rhythm, commands readers to a musical action, whereas, Bella Naija as NG is an open-statement. As a persuasive facility, the command has Predicator, Refresh and ur rhythm oriented in Theme. The marker, Refresh, is a Material Process, serving as a revitalization of musical tone purposes. The renewal is illustrated in $u r$ rhythm, functioning as Goal. The command seems periodic on the ground that it is a call on readers to reload their quests toward musical entertainment. Also striking is $u r$, which is a clip from the possessive pronoun of your (Dalamu, 2017e). Bella Naija is a slang that does not make much Register universal meaning except that Naija is coined from Nigeria. The semantic slot displays Bella Naija in the domains of Transitivity, as Participant, and Complement in the field of Mood. However, Bella Naija is Rheme in the thematic system because of the way it corresponds with Ideational and Interpersonal Metafunctions.

\section{CONCLUSIONS}

The exploration of Register in the advertising texts demonstrates advertisements with peculiar structures, inclined to language as well as its socio-cultural norms. The analysis provides semantic values to the 
grammatical structures of the texts via the semiotic slots as appeared in their transitivity, mood and thematic systems. It also discloses the settings of the texts in the forms of Field, Tenor and Mode.

As demonstrated in Figures 3, 4, and 5, Material processes dominate the frequency of the transitivity system with constructs such as introducing, come to and reshaped, and Relational process of is. Besides, there is also Existential process of There's referencing a particular situation. In the same transitivity system, Circumstances of Location (since 1945, at the top) and of Cause (of quality) operate in the communications. The interactional environment exhibits Complement (the easy way, clear) and Predicator (rests on, wasting) as the most functional devices. Also Adjunct (in our gene, only) operates well. The mood pinpoints Subject (The diff, the barman) and Finite (is, can) as remarkable element of the messages. In the textual sphere, the rhematic devices (rests on today's foundation, ur rhythm) and Theme 2 (it, Buy) are very effective in the advertising discourse. Nevertheless, Theme 1 (When) scarcely operates.

The study displays alphanumeric code (*945\# life), clipping (Bourn, diff), neologism (Pecadomo) and local language intrusion $(O g a)$ as parts of the Register of the advertisements. Apart from the general clauses of declarative and imperative observed, the investigation reveals structures such as nominal group (The shine of quality) and minor clause (Happy Children's Day...) as persuasive elements of the messages. Personification, poetic and idiomatic expressions, and codemixing are social devices utilized to convince consumers to appropriate actions as advertisers intended. Some of the Registers operate in suspense to fascinate readers to the information of the advertising plates. Time is a reckoning factor in the texts as a means to enhance and haste the behavior of consumers toward a particular direction. Based on the outcome of this analysis, the author could suggest that the deployment of language at the will of users should be encouraged as that has a capacity for language development. As SFL has served a good purpose of assessing registerial facilities of advertising texts, the theory might be applied in other textual domains for meaning derivatives.

\section{REFERENCES}

Adams, V. (2001). Complex words in English. Harlow, GB: Longman. ASL. (2003). Understanding registers of language consecutive interpreting (ASL 3330). Register variation: Formal vs informal spoken English. Retrieved on 12, 
June 2017 from https://intrpr.github.io/library/stringham-understanding-registerformality.pdf.

Bauer, L. (2001). Morphological productivity. Cambridge: Cambridge University Press.

Bloor, T., \& Bloor, M. (2004). The functional analysis of English. Great Britain: Hodder Arnold.

Bloor, T., \& Bloor, M. (2013). The functional analysis of English. Abingdon, Oxon: Routledge.

Booij, G. E. (2007). The grammar of word: An introduction to morphology). Oxford: Oxford University Press.

Brook, G. L. (1973). Varieties of English. London: MacMillan Press.

Butler, C. S. (1985). Systemic linguistics: Theory and applications. London: Batsford Academic and Educational

Butler, C. S. (2003a). Structure and function: A guide to three major structuralfunctional theories Part I. Amsterdam/Philadelphia: John Benjamins.

Butler, C. S. (2003b). Structure and function: A guide to three major structuralfunctional Theories Part II. Amsterdam/Philadelphia: John Benjamins.

Chomsky, N. \& Halle, M (1968). The sound pattern of English. New York: Harper \& Row.

Clark, J., \& Yallop, C. (1995). An introduction to phonetics and phonology. Victoria, Australia: Blackwell Publishing.

Cook, G. (2001). The discourse of advertising. New York: Routledge.

Couper-Kuhlin, E. (2002). Intonation and discourse: Current views from within. In D. Schiffrin,

D. Tannen \& H. Hamilton (Eds.), The handbook of discourse, pp. 13-34. United Kingdom: Blackwell.

Couture, B. (ed.) (1986). Functional approaches to writing: Research perspective. Norwood, NJ: Ablex Publishing.

Cross, M. (1993). Collocation in computer modeling of lexis as most delicate grammar. In M. Ghadessy (ed.), Register analysis: Theory and practice (pp. 196220). London and New York: Pinter Publisher.

Cruttenden, A. (1986). Intonation. Cambridge: Cambridge University Press.

Crystal, D. \& Davy, D. (1969). Investigating English style. Bloomington: Indiana and London: Indiana University Press and Longmans, Green.

Dalamu, T. O. (2017a). Contextualizing advertising as a communicative apparatus of text-switching. Studies in Linguistics, 42, 249-274.

Dalamu, T. O. (2017b). A preliminary exposé of systemic functional theory fundamentals. Ethical Lingua: Journal of Language Teaching and Literature, 4(2), 93-108.

Dalamu, T. O. (2017c). A functional approach to advertisement campaigns in Anglo-Nigerian Pidgin. Studies in Linguistics, 44, 155-185.

Dalamu, T. O. (2017d). Periodicity: Interpreting the flow of Osundare's 'Harvestcall.' Buckingham Journal of Language and Linguistics, 10, 4270. 
Dalamu, T. O. (2017e). A discourse analysis of language choice in $M T N^{\circledR}$ and Etisalat $^{\circledR}$ advertisements in Nigeria (Doctoral thesis, University of Lagos, Akoka, Yaba, Nigeria).

Dalamu, T. O. (2018a). Akèrègbè, resourcing the past, communicating the present in shared cultural knowledge: A case study of GTB Advertising. Communicatio 12(1), 113-137.

Dalamu, T. O. (2018b). Donald Trump's 2016 American presidential election victory remarks: An ideational perspective. Studies in Linguistics, 48, 181-234.

Dalamu, T. O. (2018c). Advertising communication: Constructing meaning potential through disjunctive grammar. Anagramas Rumbos y Sentidos De La Communicación (in press).

Dalamu, T. O. (2018d). Euphemism: The commonplace of advertising culture. Acta Scientiarum. Language and Culture (in press).

Dalamu, T. O. (2018e). English language development in Nigerian society: A derivative of advertising communications. Complutense Journal of English Studies (in press).

De Beaugrande, R. (1991). Linguistic theory: The discourse of fundamental works. London and NewYork: Longman.

De Beaugrande, R. (1993). Register in discourse studies: A concept in search of a theory. In M.

Ghadessy (ed.), Register analysis: Theory and practice (pp. 7-25). London and New York: Pinter Publisher.

Dyer, G. (2005). Advertising as communication. London: Routledge.

Eggins, S. (2004). Introduction to systemic functional linguistics. London: Continuum.

Eggins, S. and Slade, D. (1997). Analyzing casual conversation. London: Equinox.

Eggins, S., \& Martin, J. R. (1997). Genres and Register of Discourse. In Teun A. van Dijk (Ed.), Discourse as Structure and Process, Discourse Studies: A Multidisciplinary Introduction, 1, pp. 230-256. London: Sage Publications.

Ellis, J. \& Ure, J. N. (1969). Language varieties: Register. In A. R.Meetham (Ed.), Encyclopedia of Linguistics: Information and Control (pp. 251-259). Oxford: Pergamon.

Fairclough, N. (1992). Discourse and social change. Malden, USA: Polity Press.

Fairclough, N. (2001). Language and power. Harlow, England: Pearson Education.

Ferguson, Charles (1994). Dialect, register and genre: Working assumptions about convetionalization. In D. Biber \& E. Finegan (Eds.), Sociolinguistic perspective on register, pp 15-30. New York: Oxford University Press.

Ferguson, C. (ed) (1985). Special language registers. Special issue of discourse processes, 4,8 .

Ferguson, C. A. (1977). Baby talk as a simplified register. In Snow and Ferguson, pp. 219- 36.

Firth, J. R. (1950). Personality and language in society. Sociological Review, XLII, $37-52$.

Firth, J. R. (1958). Papers in linguistics 1934-1951. Oxford: Oxford University Press. 


\section{EVALUATING 'REGISTERIAL' NORMS IN ADVERTISING TEXTS: A SYSTEMIC PERSPECTIVE}

Fontaine, L. (2013). Analyzing English grammar: A systemic functional introduction. Cambridge: Cambridge University Press.

Forceville, C. (1996). Pictorial metaphor in advertising. London and New York: Routledge.

Frow, John (1980). Discourse genre. The Journal of Literary Semantics, 9, 73-79.

Geis, M. L. (1982). The language of television advertising. London and New York: Academic Press.

Ghadessy, M. (ed.) (1993), Register analysis: Theory and practice. London and New York: Pinter Publisher.

Gieszinger, S. (2001). The history of advertising language. Frankfurt: Peter Lang $\mathrm{GmbH}$.

Giles, H., Scherer, K. R., \& Taylor, Donald, M. (1979). Speech markers in social interaction. In K.R. Scherer \& H. Giles (Eds.), Social markers in speech, pp. 343382. London and Paris: Cambridge University Press and Editions de la Maison des Sciences de l'Homme

Gregory, M. (1967). Aspects of varieties differentiation. Journal of Linguistics, 3, 177-198.

Gregory, M., \& Carroll, S. (1978) Language and situation. Boston: Routledge \& Kegan.

Halliday, M.A.K. (1967/8). Notes on transitivity and theme in English 1-3. Journal of Linguistics, 3(1), 3(2) \& 4(2), 3-4.

Halliday, M.A.K. (1978). Language as social semiotic: The social interpretation of language and meaning. London: Edward Arnold.

Halliday, M. A. K. (1980a). Context of situation. Sophia Linguistica, 6, 4-15.

Halliday, M. A. K. (1980b). Functions of language. Sophia Linguistica, 6, 31-42.

Halliday, M. A. K. (1980c). Register variation. Sophia Linguistica, 6, 60-74.

Halliday, M. A. K. (1985a). Introduction to functional grammar. London: Arnold.

Halliday, M. A. K. (1985b). Systemic Background. In J. Benson \& W. Greaves (Eds.),

Systemic Perspectives on Discourse XV, pp. 1-15. Norwood, New Jersey: Ablex Publishing Corporation.

Halliday, M. A. K. (1994). An Introduction to Functional Grammar. Great Britain: Arnold.

Halliday, M. A. K., MacIntosh, A., \& Strevens, P. (1964). The linguistic sciences and language teaching. London: Longman.

Halliday, M. A K., \& Hasan, R. (1976). Cohesion in English. London: Longman.

Halliday, M. A. K., \& Hasan, R. (1985). Language, context, and text: Aspects of

language in a socio-semiotic perspective. Geelong: Deakin University Press.

Halliday, M. A. K., \& Matthiessen M. I. M. (2004). An introduction to functional grammar. Great Britain: Arnold.

Halliday, M. A. K. \& Matthiessen M. I. M (2014). Halliday's introduction to functional grammar. Abingdon, Oxon: Routledge.

Hermerén, L. (1999). English for Sale: A study of the language of advertising. Lund: LUP.

Hoey, M. (1983). On the surface of discourse. London: Allen and Unwin.

Hymes, D. (1974). Foundations in sociolinguistics: An ethnographic approach. Philadelphia: University of Pennsylvania Press.

Johnstone, B. (2008). Discourse Analysis. Oxford: Blackwell Publishing. 
Joos, M. (1967). The five clocks of language. San Diego: Harcourt Brace

Kołata, J. (2010). The reformulation of genre and register analysis. Styles of Communication, 2, 50-74. Retrieved on 30 august, 2017 from file://C:/Users/user/Downloads/733-2742-2-PB.pdf

Kress, G., \& Leeuwen, T. (2003). The grammar of visual design. London and New York: Routledge.

Leckie-Tarry, H. (1993). The specification of text: Register, genre and language teaching. In M. Ghadessy (Ed.), Register analysis: Theory and practice (pp. 2642). London and New York: Pinter Publisher.

Leech, G. (1966). English in advertising: A linguistic study of advertising in Great Britain. London: Longman.

Lemke, J. (1990). Ideology, intertextuality, and the notion of register. In Benson, J. \& W. Greaves (Eds.), Systemic Perspectives on Discourse XV, pp. 275-294. Norwood, New Jersey: Ablex Publishing Corporation.

Malinowski, B. (1923). The problem of meaning in primitive languages. In Ogden C. K. \& A. Richard (Eds.), The meaning of meaning. New York: Harcourt Brace.

Martin, J. R. (1985). Process and text: Two aspects of human semiosis. In J. Benson \& W. Greaves (eds.), Discourse Processes, pp. 247-274. Norwood, NJ: Ablex Publishing.

Martin, J. R. (1992). English text: System and structure. Philadelphia: John Benjamins Publishing.

Martin, J. R. (1993). Genre and literacy - modeling context in educational linguistics. Annual Review of Applied Linguistics, 13, 141-74.

Martin, J. R. (2002). Cohesion and text. In D. Schiffrin, D, Tannen \& H. Hamilton (Eds.), The handbook of discourse, pp. 35-53. United Kingdom: Blackwell.

Martin, J. R., \& Rothery, J. (1986). What a functional approach to the writing task can show Teachers about good writing. In B. Couture (Ed.), Functional approaches to writing: Research perspectives, pp. 241-265. Norwood, NJ: Ablex.

Martin, J. R. \& Rose, C. (2013). Working with discourse: Meaning beyond the clause. London and New York: Bloomsbury Academy.

Matthiessen, C. (1993). Register in the round: Diversity in a unified theory of register analysis.

In M. Ghadessy (Ed.), Register analysis: Theory and practice (pp. 221-392). London and New York: Pinter Publisher.

McCarthy, M. \& Carter, R. (1994). Language as discourse: Perspective for language teaching. New York: Longman Group.

Myers, G. (1994). Words in ads. London and New York: Arnold.

Ogilvy, D. (2013). Confession of an advertising man. Harpenden: Southbank Publishing.

Okoro, O. (2008). Exploring collocations in Nigerian English usage. In A. Daramola $\& \mathrm{O}$.

Olugasa (eds.), Literature and language: A drama of life - Festschrift in honor of Z. A. Adejumo, (pp. 113-140). Lagos: BPrint.

Packard, Vance (2007). The hidden persuaders. Brooklyn, New York: Ig Publishing.

Rashidi, L. S. (1992). Towards an understanding of the notion of Theme: An example from Dari.

In L. Ravelli \& F. Christie (Eds.), Advances in Systemic Linguistics, Recent Theory and practice, pp.189-204. London: Continuum. 


\section{EVALUATING 'REGISTERIAL' NORMS IN ADVERTISING TEXTS: A SYSTEMIC PERSPECTIVE}

Ravelli, L. (2000). Getting started with functional analysis of texts. In L. Unsworth \& F. Christie

(Eds.), Researching Language in Schools and Communities, pp. 27-63. London: Cassell.

Reid, T. B. W. (1956). Linguistics, structuralism, philology. Archivum Linguisticum, 8, 28-37.

Sinclair, J. McH. (1981). Planes of discourse. In S. N. A. Rizvi (Ed.), The two-fold voice: Essaya

In honor of Ramesh Mohan, pp. 70-89. Saltzburg: Universitat Saltzburg.

Snow, C. E. \& Ferguson, C. A. (eds.) (1977). Talking to children. London: Cambridge University Press.

Tanaka, K. (1994). Advertising Language: A pragmatic approach to advertisements in Britain and Japan. London: Routledge.

Thibault, P. (1987). An interview with Michael Halliday. In R. Steele \& T. Threadgold (Eds.),

Language topics: Essays in honour of Michael Halliday, 2, 599-627. Amsterdam: Benjamins.

Thompson, G. (2004). Introducing functional grammar. Great Britain: Hodder Arnold.

Thompson, G. (2014). Introducing functional grammar. Abingdon, Oxon: Routledge.

Ure, J. (1968). Practical registers. English Language Teaching, 23, 107-215.

Uribe-Villegas, O. (ed.) (1977). Issues in sociolinguistics. The Hague: Mouton.

Vestergaard, T., \& Schroder, K. (1985). The language of advertising. Oxford and New York:

Basil Blackwell.

Webster, J. J. (1993). Text processing using the Functional Grammar Processing (FGP). In M.

Ghadessy (ed.), Register analysis: Theory and practice, pp. 181-195. London and New York: Pinter Publisher.

Wicke, J. (1988). Advertising fiction: Literature, advertising and social reading. New York: Columbia University Press.

Williamson, J. (1978). Decoding advertising: Ideology and meaning in advertising. New York:

Marion Boyars.

Winter, E. O. (1982). Toward a contextual grammar of English: The clause and its place in the

definition of sentence. London: Allen and Unwin.

Xhignesse, M. A. (2016). The trouble with poetic licence. British Journal of Aesthetics 56 (2),

149-161. DOI: https://doi.org/10.1093/aesthj/ayv053. Retrieved on May 27, 2017 from https://academic.oup.com/bjaesthetics/articleabstract/56/2/149/2195135/The. Trouble-with-PoeticLicence?redirectedFrom $=$ PDF.

Yule, G. (1996). The study of language. Cambridge: Cambridge University Press.

Zapata Becerra, A. A. (2007). Types of words and word-formation processes in English: Inglés

$I V$. Retrieved from 
VOLUME 102018

http://webdelprofesor.ula.ve/humanidades/azapata/materias/english_4/unit 1 types_o f words and word formation processes.pdf.

Zwicky, Ann D., \& Zwicky, Arnold, M. (1980). America's national dish: The style of restaurant

menus. American Speech, 55, 83-92.

Zwicky, Ann D. \& Zwicky, Arnold, M. (1980). Register as a dimension of linguistic variation. In

R. Kittredge \& J. Lehrberger (Eds.), Sublanguage: Studies of language in restricted domains, pp. 213-218. B erlin: Walter de Gruyter. 